\title{
MANAJEMEN STRATEGI PENGELOLAAN SUMBER DAYA MARITIM DI INDONESIA
}

\author{
Ari Wibowo ${ }^{1)}$, Eka Prabawa ${ }^{2}$, Endun Sugiarto ${ }^{3}$ \\ ${ }^{1,2,3}$ SESKO Angkatan Laut, Jakarta, Indonesia \\ Ariwibowo5004@gmail.com
}

\begin{abstract}
ABSTRAK
Penelitian ini akan mengkaji tentang potensi dan pengelolaan sumberdaya laut masyakarat pesisi. Tujuan dari pembangunan sumberdaya laut berkelanjutan adalah: Dalam perspektif bertujuan untuk menyiapkan wilayah pertahanan laut dan kekuatan pendukungnya secara dini dalam rangka memenangkan peperangan. Dalam perspektif kepentingan masyarakat bertujuan untuk membantu mengatasi kesulitan masyarakat dan meningkatkan kesejahteraan masyarakat maritim. Dalam perspektif kepentingan TNI bertujuan untuk tercapainya tugas pokok TNI Angkatan Laut, dalam meningkatkan pertahanan negara. Tujuan umum dari penelitian ini adalah menganalisis implikasi pembangunan sumberdaya laut berkelanjutan Dalam Meningkatkan sistem tata kelola maritim. Penelitian menggunakan metode kualitatif. Data diperoleh dari para informan yang ditetapkan dan selanjutnya dianalisis dengan teknik analisis kualitatif.
\end{abstract}

Kata Kunci: Strategi Pengelolaan, Sumberdaya Pesisir Laut dan Sistem Tata Kelola Maritim

\begin{abstract}
This research will examine the potential and management of coastal marine resources. The objectives of sustainable marine resource development are: In perspective, it aims to prepare the marine defense area and its supporting forces early in order to win the war. In the perspective of community interests, it aims to help overcome community difficulties and improve the welfare of the maritime community. In the perspective of the interests of the TNI, it aims to achieve the main task of the Navy, in improving national defense. The general objective of this study is to analyze the implications of sustainable marine resource development in improving maritime governance systems. The research uses qualitative methods. Data were obtained from the informants who were determined and then analyzed using qualitative analysis techniques.
\end{abstract}

Keywords: Management Strategy, Coastal Marine Resources and Maritime Governance System

\section{PENDAHULUAN}

Sumber daya laut di Indonesia memiliki tingkat biodiversitas yang sangat tinggi.Hal ini dibuktikan dengan sebutan Indonesia sebagai Marine Mega-Biodiversity terbesar di dunia. Indonesia memiliki sekitar 8.500 spesies ikan, 555 spesies rumput laut dan 950 spesies biota terumbu karang. Tiga puluh tujuh persen spesies ikan di dunia dapat ditemukan di Indonesia dan beberapa spesies ikan tersebut memiliki nilai ekonomis tinggi.Ikan-ikan dengan nilai ekonomis tinggi seperti tuna, cakalang, udang, tenggiri, kakap, cumi-cumi dan ikan-ikan karang seperti kerapu, baronang dan lobster. Sedangkan untuk potensi perikanan tangkap laut sekitar 6,5 juta ton/tahun, perikanan budidaya air payau mencapai 2,9 juta hektar dan potensi budidaya laut mencapai 12,55 juta hektar (Sutardjo, 2014). Namun sangat disayangkan melihat kenyataan bahwa sumber daya laut yang melimpah tersebut belum bisa dimanfaatkan secara maksimal untuk mesejahterakan negara.Sektor maritim tergolong sangat tertinggal mulai dari pemanfaatan sumber daya, teknologi, tingkat kemiskinan dan keterbelakangan nelayan. Munculnya permasalahan-permasalahan tersebut disebabkan oleh persoalan yang bersifat strukturat dan Indonesia saat ini memiliki kecenderungan mengutamakan pertumbuhan ekonomi di sektor non maritim (Puspitarini \& Yunus, 2019).Selain itu, ilmu pengetahuan dan teknologi mengenai kelautan dan kemaritiman di Indonesia sangat kurang dan tertinggal. Penelitian-penelitian ilmiah kelautan dan kemaritiman pun belum mampu memberikan banyak kontribusi pada masyarakat dan belum mampu memberikan saran kebijakan yang praktis untuk pembangunan kelautan dan kemaritiman Indonesia (Asmara, 2012).

Laut, pesisir, dan sungai merupakan urat nadi yang menjadi kekuatan bangsa ini sejak dulu. Di tiga wilayah ini pelabuhan-pelabuhan besar dibangun yang diramaikan dengan aktivitas pedagang dari 
berbagai pulau di Nusantara dan dari belahan dunia. Hal itu membuat perekonomian dan peradaban maju dan berkembang. Kemampuan mengelola maritim itu disadari oleh Belanda, karena itu Belanda mendesak pribumi menjauhi laut menuju daratan hingga pegunungan. Sejak itu pertanian daratan menjadi berkembang.

Budaya maritim menjadi bagian yang tak terpisahkan dari kehidupan masyarakat, khususnya yang terkait dengan maritim dan kelautan. Para nelayan dan masyarakat pesisir, misalnya, memiliki kearifan lokal dalam mengelola dan memanfaatkan sumberdaya laut, sehingga keberlanjutan sumber kehidupan mereka tetap terjamin hingga ke anak cucu. Salah satu bukti warisan budaya sebagai bangsa pelaut yang hingga kini masih ada adalah Kapal Pinisi.

Potensi maritim dan kelautan yang begitu besar seharusnya dimanfaatkan untuk menyejahterakan masyarakat. Namun, kenyataannya potensi itu belum dimanfaatkan dengan optimal. Hal itu berkontribusi pada angka kemiskinan yang masih tinggi. Sebagian diantaranya adalah nelayan dan masyarakat pesisir terkait yang tergolong kelompok paling miskin. Eksploitasi dan kegiatan ilegal terhadap sumberdaya laut tanpa memperhatikan keberlanjutan memperburuk tingkat kesejahteraan dan kehidupan nelayan, khususnya nelayan kecil dan nelayan tradisional. Pencurian ikan yang dilakukan oleh nelayan asing, misalnya, di samping mengurangi pendapatan nelayan, juga merugikan negara. Pencemaran laut dan kerusakan mangrove dan terumbu karang juga menambah masalah di sektor kelautan. Berdasarkan isu tersebut, perlu adanya tata kelola maritim secara terpadu serta bentuk implementasi pembangunan berkelanjutan diperlukan untuk mengelola sumber daya laut di Indonesia. Sehingga tujuan untuk mengedepankan kesejahteraan bangsa dan negara untuk kedaulatan negara melalui sektor kemaritiman dapat tercapai.

\section{Strategi Pengelolaan}

Kata strategi berasal dari kata Strategos dalam bahasa Yunani merupakan gabungan dari Stratos atau tentara dan ego atau pemimpin. Suatu strategi mempunyai dasar atau skema untuk mencapai sasaran yang dituju. Jadi pada dasarnya strategi merupakan alat untuk mencapai tujuan jangka panjang. Menurut Marrus (2002), strategi didefinisikan sebagai suatu proses penentuan rencana para pemimpin puncak yang berfokus pada tujuan jangka panjang organisasi, disertai penyusunan suatu cara atau upaya bagaimana agar tujuan tersebut dapat dicapai. Selanjutnya Quinn (1999), mengartikan strategi adalah suatu bentuk atau rencana yang mengintegrasikan tujuan-tujuan utama, kebijakan-kebijakan dan rangkaian tindakan dalam suatu organisasi menjadi suatu kesatuan yang utuh. Strategi diformulasikan dengan baik akan membantu penyusunan dan pengalokasian sumberdaya yang dimiliki perusahaan menjadi suatu bentuk yang unik dan dapat bertahan.

Secara umum konsep strategi pengelolaan diartikan sebagai suatu rangkaian kebijakan atau tindakan yang dilakukan secara terus menerus, dengan manfaatkan peluang, ancaman dan sumberdaya serta kemampuan yang dimiliki, pada setiap tahap perencanaan, pengorganisasian, penggerakan dan pengawasan untuk mencapai tujuan yang telah ditetapkan sebelumnya secara berkelanjutan. Dengan demikian pengamatan lingkungan eksternal dan internal merupakan proses awal dari konsep strategi pengelolaan, dilanjutkan dengan perencanaan yang keberadaanya diperlukan untuk memberikan arah dan patokan dalam suatu kegiatan. Pengorganisasian berkaitan dengan penyatuan seluruh sumberdaya dan kemampuan yang ada untuk bersinergi dalam mempersiapkan pelaksanaan kegiatan. Tahap selanjutnya adalah pengarahan dan pelaksanaan kegiatan yang selalu berpedomaan pada perencanaan yang telah ditetapkan. Tahap terakhir adalah pengawasan yang meliputi kegiatan monitoring dan evaluasi untuk memperbaiki program kegiatan berikutnya sehingga tujuan yang telah direncanakan tercapai dengan baik.

\section{Potensi Sumberdaya Pesisir dan Laut}

Daerah pesisir dan laut memiliki berbagai macam keanekaragaman hayati yang mempunyai peranan dan fungsi masing-masing dalam menjaga keseimbangan ekosistem. Keanekaragaman hayati tersebut merupakan potensi sumberdaya yang mampu menyokong kehidupan masyarakat pesisir dalam peningkatan kualitas kehidupan yang lebih baik. Sumberdaya pesisir dan laut secara garis besar dibagi kedalam tiga bagian, yaitu: sumber daya alam hayati, non hayati (mineral), dan energi. Ketiga jenis sumberdaya tersebut merupakan kekayaan alam yang potensial untuk dikembangkan dan dikelola sebagai sektor pembangunan andalan di masa datang. 
Suatu wilayah pesisir, di dalamnya terdapat satu atau lebih sistem lingkungan (ekosistem) dan sumberdaya pesisir. Ekosistem pesisir dapat bersifat alami ataupun buatan (man-made). Ekosistem alami yang terdapat di wilayah pesisir antara lain adalah terumbu karang (coral reefs), hutan mangrove, padang lamun (sea grass), pantai berpasir (sandy beach), formasi pes-caprea, formasi baringtonia, estuari, laguna dan delta. Ekosistem buatan antara lain berupa; tambak sawah pasang surut, kawasan pariwisata, kawasan industri, kawasan agroindustri dan kawasan pemukiman. Sumberdaya pesisir merupakan salah satu kekayaan alam yang banyak dimanfaatkan oleh masyarakat, akan tetapi pemanfaatan sumberdaya tersebut sampai saat ini kurang memperhatikan kelestariannya, akibatnya terjadi penurunan fungsi, kualitas serta keanekaragaman hayati yang ada.

Sumberdaya yang dapat pulih terdiri dari berbagai sumberdaya perikanan (plankton, benthos, ikan, moluska, krustasea, mamalia laut), rumput laut (seaweed), padang lamun (seagrass), hutan mangrove dan terumbu karang, termasuk kegiatan budidaya pantai dan budidaya laut (marine culture).

\section{Pengelolaan Sumberdaya Pesisir dan Laut}

Pengelolaan sumberdaya alam adalah usaha manusia dalam mengubah ekosistem untuk memperoleh manfaat maksimal, dengan mengupayakan kesinambungan produksi dan menjamin kelestarian sumberdaya tersebut (Afiati, 1999). Pengelolaan sumberdaya pesisir dan laut pada hakekatnya adalah suatu proses pengontrolan tindakan manusia atau masyarakat di sekitar kawasan pesisir agar pemanfaatan sumberdaya alam dapat dilakukan secara bijaksana dengan mengindahkan kaidah kelestarian lingkungan (Supriharyono, 2002).

Dalam pengelolaan lingkungan sumberdaya pesisir tidaklah bersifat serta merta atau latah, namun kita perlu mengkaji secara mendalam isu dan permasalahan mengenai sumberdaya yang hendak dilakukan pengelolaan. Penting atau tidaknya sumberdaya alam yang ada, potensi dan komponen sumberdaya mana yang perlu dilakukan pengelolaan dan apakah terdapat potensi dampak perusakan lingkungan, serta untung atau tidaknya sumberdaya tersebut bagi masyarakat merupakan pertimbangan penting dalam pengelolaan.

\section{METODE}

Penelitian ini menggunakanan metode penelitian kualitatif. Penelitian kualitatif merupakan penelitian yang dilakukan untuk mencari makna, pemahaman, pemngertian tentang suatu fenomena, kejadian, maupun kehidupan manusia dalam setting atau latar alamiah, kontekstual dan menyeluruh. Dalam hal ini, peneliti kualitiaitif berupaya mengerti makna dari suatu peristiwa. Pemahaman makna tentang sesuatu dalam penelitian kualitatif selalu menempatkan subjek penelitian dalam posisi yang sama dengan peneliti (Yusuf, 2014).

Penelitian kualitatif lebih bersifat deskriptif, sehingga disebut juga dengan deskriptif kualitatif. Penelitian dengan format deskriptif kualitatif (Bungin,2017) bertujuan untuk menggambarkan, meringkas berbagai kondisi atau realitas sosial yang ada di masyarakat yang menjadi objek penelitian. Penelitian ini menggunakan metode kualitatif karena bertujuan untuk memberikan deskripsi dan mengungkapkan makna serta melihat proses tentang pembangunan sumber daya laut berkelanjutan, dimana pembinaan yang dilakukan berbasis budaya lokal dalam sistem tata kelola maritim.

Sumber data pada penelitian ini terdiri dari data primer dan data sekunder. Pada penelitian kualitatif, instrument penelitian utama adalah manusia, yaitu peneliti. Peneliti dapat meminta bantuan orang lain untuk membantu melakukan wawancara yang disebut dengan pewawancara (Afrizal,2014). Dalam mengumpulkan data di lapangan, peneliti memerlukan instrumen tambahan yang dapat membantu pengumpulan data lebih efektif. Instumen tersebut dapat berupa pedoman wawancara, alat perekan, alat tulis, kamera untuk dokumentasi kegiatan, dan alat-alat lainnya yang relevan. Teknik pengumpulan data pada penelitian ini dilakukan dengan cara observasi, wawancara dan studi kepustakaan.

\section{PEMBAHASAN}

\section{Implementasi Pembangunan Sumber Daya Laut Berkelanjutan}

Pengaturan pengelolaan perikanan yang bertanggung jawab (responsible fisheries) tidak saja mendapatkan pengaturan secara nasional tetapi juga pengaturan secara internasional. Pemanfaatan sumber daya ikan yang terdapat di ZEE sesuai dengan amanah UNCLOS III, maka dalam rangka 
konservasi sumber daya ikan, Indonesia menetapkan bahwa diizinkannya negara lain dapat berpartisipasi di ZEE Indonesia jika JTB untuk jenis tersebut melebihi kemampuan Indonesia untuk memanfaatkannya. Sehingga pemanfaatan yang melibatkan negara lain tetap dalam koridor pengelolaan yang didasarkan pada ketersediaan objeknya (sumber daya ikan). Pada prinsipnya pengaturan sumber daya ikan secara nasional berlandaskan pada Pasal 3 Undang-Undang Nomor 45 Tahun 2009 tentang Perubahan Atas Undang-Undang Nomor 31 Tahun 2004 tentang Perikanan, sebagai berikut (FAO,1995): Pasal 5 (3) Undang-Undang Nomor 5 Tahun 1983 tentang Zona Ekonomi Eksklusif Indonesia, LNRI Tahun 1983 Nomor 44, TLNRI Nomor 3260. Bandingkan Pasal 61 ayat (1) dan Pasal 62 ayat $(1,2)$.

1. Meningkatkan taraf hidup nelayan kecil,

2. Meningkatkan penerimaan dan devisa negara,

3. Mendorong perluasan dan kesempatan kerja,

4. Meningkatkan ketersediaan dan konsumsi sumber protein ikan,

5. Mengoptimalkan pengelolaan sumber daya ikan,meningkatkan produktivitas, mutu, nilai tambah dan daya saing,

6. Meningkatkan ketersediaan bahan baku untuk industri pengolahan ikan,

7. Mencapai pemanfaatan sumber daya ikan dan lingkungan sumber daya ikan secara optimal dan menjamin kelestarian sumber daya ikan.

Selanjutnya dalam penjabaran ketentuan Pasal 6 ayat (1) tersebut di atas oleh pemerintah Indonesia telah diatur dan ditetapkan potensi sumber daya ikan dan JTB menurut kelompok jenis ikan dan wilayah pengelolaan di Wilayah Pengelolaan Perikanan Republik Indonesia (WPP). Dalam rangka pengelolaan perikanan yang menjamin kelestarian sumber daya ikan di lingkungan seluruh Indonesia, wilayah pengelolaan perikanan kemudian diubah dari 9 WPP menjadi 11 WPP. Sesuai dengan amanah UndangUndang Nomor 31 Tahun 2004 tentang Perikanan yang telah direvisi dengan Undang-Undang Nomor 45 Tahun 2009 tentang Perubahan Atas Undang-Undang Nomor 31 Tahun 2004 tentang Perikanan, maka Menteri menindaklanjuti dengan menetapkan ketentuan pengelolaan perikanan. Dalam rangka mendukung kebijakan pengelolaan sumber daya ikan tersebut, Menteri menetapkan:

1. Rencana pengelolaan perikanan;

2. Potensi dan alokasi sumber daya ikan di wilayah pengelolaan perikanan negara republik indonesia;

3. Jumlah tangkapan yang diperbolehkan di wilayah pengelolaan perikanan negara republik indonesia; potensi dan alokasi induk serta benih ikan tertentu di wilayah pengelolaan perikanan negara republik indonesia;

4. jenis, jumlah dan ukuran alat penangkapan ikan;

5. jenis, jumlah, ukuran dan penempatan alat bantu penangkapan ikan;

6. Daerah, jalur dan waktu atau musim penangkapan ikan;

7. Persyaratan atau standar prosedur

8. Pelabuhan perikanan;

9. Sistem pemantauan kapal perikanan;

10. Pencegahan pencemaran dan kerusakan sumber daya ikan serta lingkungannya;

11. Rehabilitasi dan peningkatan sumber daya ikan serta lingkungannya;

12. Ukuran atau berat minimum jenis ikan yang boleh ditangkap;

13. Kawasan konservasi perairan;

14. Kenis ikan yang dilarang untuk diperdagangkan, dimasukkan, dan dikeluarkan ke dan dari wilayah negara republik indonesia; dan

15. Jenis ikan yang dilindungi

Konsep pembangunan perikanan berkelanjutan telah dipesankan dalam CCRF bahwa pengelolaan perikanan yang bertanggung jawab adalah pengelolaan yang dapat menjamin keberlanjutan perikanan dengan suatu upaya agar terjadi keseimbangan antara tingkat eksploitasi dengan sumber daya ikan. Kepentingan keberlanjutan perikanan tidak hanya untuk kepentingan pemerintah saja, tetapi justru kepentingan pengguna perikanan yang mempunyai kaitan langsung dengan perikanan.

Konsep pembangunan berkelanjutan adalah upaya yang bertujuan untuk mensinkronkan, mengintegrasikan, dan memberi bobot yang sama pada aspek utama pembangunan, yang meliputi tidak hanya aspek ekonomi, tetapi termasuk aspek yang melingkupinya, yaitu termasuk aspek sosial budaya 
dan aspek lingkungan hidup. Aspekaspek utama tersebut harus dipandang sebagai terkait erat satu sama lain, sehingga unsur-unsur dari kesatuan yang saling terkait ini tidak boleh dipisahkan atau dipertentangkan satu dengan lainnya.

Pembangunan perikanan berkelanjutan sebagai upaya yang bertujuan untuk mensinkronkan, mengintegrasikan, dan memberi bobot yang sama pada aspek utama pembangunan, yang meliputi sistem perairan (aquatic system), sistem manusia (human system), dan sistem kelembagaan dan kebijakan perikanan (institutional and policy system). Dapat dicontohkan pada saat terjadinya kekosongan hukum pengaturan perikanan internasional yang terjadi sekitar tahun tujuh puluhan, yang diakibatkan tidak dapat dipertahankannya kesepakatan UNCLOS I dan tidak dicapainya kata sepakat dalam UNCLOS II (Josef, 1996). Apa yang terjadi pada saat itu, tidak dapat dihentikannya pengeksploitasian sumber daya ikan secara besar-besaran ketika perikanan dunia sudah menjadi sektor industri pangan yang berkembang dengan pesat dan digerakkan oleh pasar. Akibatnya dalam beberapa tahun kemudian, ketersediaan sumber daya ikan tidak dapat lagi memenuhi kebutuhan akan permintaan pasar. Keadaan ini mendesak diperlukan upaya pengaturan konservasi sumber daya ikan.

\section{Sistem Tata Kelola Maritim}

Sistem tata kelola maritim Bangsa Indonesia selama ini masih belum terpadu, masih bersifat sektoral oriented, dan fragmented, sehingga pelaksanaannya sering terjadi tumpang tindih. Semua ini disebabkan belum adanya grand design pembangunan bidang kemaritiman dan kelautan Indonesia yang melibatkan peran semua stakeholders secara rinci dan terpadu. Sistem tata kelola maritim nasional harus terintegrasi, komprehensif, efektif dan efisien dengan harmonisasi sistem hukum nasional di bidang kemaritiman dan pembangunan sistem tata pemerintahan di bidang kelautan tingkat daerah maupun pusat juga harus dilakukan secara efisien dan terintegrasi.

Melihat potensi konflik perairan di kawasan Asia Pasifik yang melibatkan dua negara besar yakni Tiongkok dan Amerika, ada persaingan pengaruh langsung di Samudera Hindia dan Laut Cina Selatan, dimana Indonesia berada di tengah-tengahnya memungkinkan eskalasi ketegangan kawasan di Asia Pasifik. Konsep Indonesia sebagai negara maritim harus mampu memanfaatkan wilayah laut sebagai pengembangan kekuatan geopolitik, kekuatan militer, kekuatan ekonomi, hingga kekuatan budaya bahari. Kondisi geografis dan demografis Indonesia membawa konsekuensi munculnya berbagai tantangan nyata bagi Indonesia yang harus dikelola secara komprehensif.

Membangun infrastruktur maritim seperti pelabuhan-pelabuhan yang menjadi simpul aktivitas perdagangan dan penyediaan sarana perhubungan berstandar internasional, serta sarana jasa penunjang aktivitas perdagangan di kawasan pinggiran Indonesia. Konektivitas harus menjadi tulang punggung pembangunan yang Indonesiasentris, bukan Jawasentris. Pengembangan wilayah dan peningkatan aktivitas ekonomi memerlukan tata ruang laut yang komprehensif untuk mendukung pemanfaatan sumber daya kelautan secara optimal dan berkelanjutan. Tata ruang laut akan memberikan kepastian hukum dan alokasi ruang bagi pemanfaatan sumber daya kelautan sehingga tidak ada tumpang tindih pemanfaatan di lokasi yang sama.

Sumber daya alam hayati di laut Indonesia seperti perikanan perlu dijaga dengan baik dari praktik-praktik perikanan yang tidak lestari seperti Illeqal Unreported and Unregulated Fishing (IUUF) dan fisheries crimes baik dilakukan asing maupun domestik. Selain itu, budi daya perikanan laut (marine aquaculture) termasuk juga rumput laut perlu dikembangkan secara maksimal dan kekayaan laut di bidang perikanan perlu dimanfaatkan untuk kesejahteraan rakyat. Pemanfaatan minyak, gas, mineral, arus, dan ombak untuk keperluan energi dan mineral masa depan. Sumber daya alam nonhayati yang tidak terbarukan seperti minyak, gas, dan mineral, serta sumber daya alam nonhayati yang terbarukan seperti energi angin, arus, dan ombak masih belum dimanfaatkan secara optimal oleh bangsa Indonesia.

Hasil tambang energi dan mineral dasar laut, memiliki nilai ekonomi yang sangat tinggi bagi kemajuan dan kesejahteraan Indonesia. Oleh karena itu, Indonesia harus terus menyediakan data, baik secara tekstual maupun geospasial dalam bentuk peta geologi, oseanografi, hidrografi, dan keanekaragaman hayati, serta data tentang kandungan kekayaan perairan Indonesia, terutama di laut dalam Indonesia. Indonesia juga menghadapi tantangan untuk menambah luas yurisdiksi landas kontinen di luar 200 mil laut dan mampu melakukan eksplorasi di wilayah "The Area" yang berada di luar perairan intemasional. Usaha ini harus dilakukan bersama-sama dengan usaha mengembangkan 
Kebijakan: Jurnal Ilmu Administrasi

Volume 12, Nomor 2, Juni 2021

E-ISSN: 2656-2820

P-ISSN 1829-5762

kemampuan sumber daya manusia, kemampuan pendanaan, serta kemampuan penguasaan ilmu pengetahuan dan teknologi untuk mengelola sumber daya alam pada kawasan dasar laut internasional.

Pengembangan jasa logistik pelabuhan, galangan kapal, dan wisata bahari. Ekonomi maritim Indonesia tidak hanya dari kekayaan sumber daya alam hayati dan nonhayati, tetapi juga harus mengembangkan bidang jasa logistik pelabuhan kapal niaga, kapal perintis, dan kapal pesiar, wisata bahari, serta galangan kapal modern dan tradisional yang mencerminkan tradisi bahari, ahli navigasi, pelaut, dan awak kapal. Pengembangan sektor jasa tersebut memerlukan upaya tersendiri, baik dari sisi teknologi, kapasitas sumber daya manusia maupun akses pendanaannya. Kegiatan jasa kemaritiman dan eksploitasi sumber daya alam hayati dan nonhayati secara langsung dalam jangka pendek dan jangka panjang dapat membawa dampak pencemaran lingkungan hidup dan perusakan keanekaragaman hayati. Luas laut Indonesia juga membawa konsekuensi polusi dari wilayah negara lain, baik polusi darat, polusi kapal maupun anjungan dari kegiatan eksploitasi sumber daya alam.

Penghitungan ekonomi maritim pada tingkat nasional diperlukan untuk menilai secara objektif besaran ekonomi maritim Indonesia secara menyeluruh, termasuk kontribusi sektor maritim pada Produk Domestik Bruto (PDB). Perhitungan tersebut digunakan sebagai dasar perencanaan pembangunan kelautan. Gerakan desentralisasi kelautan berawal dari era reformasi, dimana pemerintah daerah provinsi diberi kewenangan mengelola sumber daya kelautan, termasuk pulau-pulau kecil dalam radius 12 mil laut, serta kabupaten/kota diberikan hak bagi hasil laut dari pengelolaan sumber daya kelautan dalam wilayah 4 mil laut. Di samping itu pemerintah daerah dan masyarakat secara terukur dilibatkan dalam pengawasan wilayah laut. Hal tersebut, perlu mendapatkan perhatian khusus dalam desain hubungan pemerintah pusat dan pemerintah daerah, serta masyarakat dalam kaitannya dengan rancang bangun kelembagaan pusat dan daerah.

Perkembangan lingkungan strategis Indonesia mengalami perubahan pesat yang tidak pernah terbayangkan satu dekade lalu. Kondisi geopolitik dan geostrategik di Asia Timur dan Asia Tenggara yang diwarnai oleh sejumlah ketegangan berpotensi berkembang menjadi sumber konflik baru yang dapat mengganggu ketahanan regional. Untuk itu, Indonesia harus mampu menunjukkan kepemimpinan (leadership) dalam bidang kelautan regional dan global, meningkatkan kerja sama bilateral dengan negara-negara strategis, serta memainkan peran kepemimpinan dalam menciptakan suatu arsitektur keamanan di Asia. Dimensi maritim yang kuat harus mampu mewakili implementasi politik luar negeri bebas aktif yang tercermin dalam sumber daya diplomasi yang memadai.

Kemampuan nasional dalam pendidikan maritim, serta penguasaan dan pemanfaatan ilmu pengetahuan dan teknologi kelautan, dimulai dari penyiapan SDM melalui pendidikan menengah dan tinggi yang diwujudkan dengan pemberian beasiswa sekolah teknis maritim sampai dengan peningkatan kapasitas riset dan pengembangan. Di samping itu, dalam rangka penyiapan sumber daya manusia bidang kelautan dan peningkatan kemampuan pemanfaatan ilmu pengetahuan dan teknologi, diperlukan juga strategi untuk meningkatkan keseimbangan kualitas sumber daya manusia sektor kelautan antarwilayah di Indonesia, terutama di wilayah pinggiran dan Indonesia Bagian Timur. Sasaran sebagai misi dari Kebijakan Kelautan Indonesia, yaitu:

1. Terkelolanya sumber daya kelautan secara optimal dan berkelanjutan;

2. Terbangunnya kualitas sumber daya manusia, ilmu pengetahuan dan teknologi kelautan yang andal;

3. Terbangunnya pertahanan dan keamanan kelautan yang tangguh;

4. Terlaksananya penegakan kedaulatan, hukum, dan keselamatan di laut;

5. Terlaksananya tata kelola kelautan yang baik;

6. Terwujudnya kesejahteraan masyarakat pesisir dan pulau-pulau kecil yang merata;

7. Terwujudnya peningkatan pertumbuhan ekonomi dan industri kelautan yang berdaya saing;

8. Terbangunnya infrastruktur kelautan yang andal;

9. Terselesaikannya aturan tentang tata ruang laut;

10. Terlaksananya pelindungan lingkungan laut;

11. Terlaksananya diplomasi maritim; dan

12. Terbentuknya wawasan identitas, dan budaya bahari.

Kebijakan sumber daya kelautan bertujuan untuk mendorong pemanfaatan dan pengusahaan sumber daya kelautan secara optimal dan berkelanjutan melalui penerapan prinsip ekonomi biru. Pertumbuhan ekonomi di bidang kelautan diwujudkan melalui pembangunan 
Kebijakan: Jurnal Ilmu Administrasi

Volume 12, Nomor 2, Juni 2021

E-ISSN: 2656-2820

P-ISSN 1829-5762

berkelanjutan yang efisien, bernilai tambah, inklusif, dan inovatif sebagai penunjang seluruh aktivitas ekonomi yang meliputi perdagangan barang, jasa, dan investasi untuk sebesar-besarnya kemakmuran rakyat. Program-program utama dalam melaksanakan strategi pengelolaan sumber daya kelautan, sebagai berikut:

a. Pengelolaan dan pemanfaatan sumber daya perikanan secara lestari;

b. Peningkatan pengolahan, pemasaran, nilai tambah, serta standar dan keselamatan produk kelautan dan perikanan;

c. Peningkatan pelindungan terhadap kelestarian keanekaragaman hayati laut melalui konservasi ekosistem, jenis, dan genetik;

d. Pengembangan dan pemanfaatan energi dan sumber daya mineral sesuai dengan pnnsip ekonomi biru dengan memperhatikan teknologi ramah lingkungan;

e. Pemanfaatan secara berkelanjutan sumber daya alam nonkonvensional berdasarkan prinsip kelestarian lingkungan;

f. Pengembangan pariwisata bahari berkelanjutan dengan memperhatikan kepentingan masyarakat lokal, kearifan tradisional, kawasan konservasi perairan, dan kelestarian lingkungan;

g. Pengembangan industri bioteknologi kelautan dan biofarmakologi laut dengan pemanfaatan potensi keanekaragaman hayati;

h. Peningkatan pengelolaan dan pemanfaatan sumber daya pesisir dan pulau-pulau kecil secara seimbang dan berkelanjutan; dan

i. Penguatan sistem data dan informasi kelautan, inventarisasi, dan evaluasi sumber daya kelautan.

\section{SIMPULAN}

Sumberdaya pesisir dan laut merupakan ekosistem yang sangat strategis bagi pembangunan nasional, maka dalam penetapan program dan kebijakannya harus diupayakan adanya efisiensi dalam pemanfaatan ruang dan sumberdaya pesisir, peningkatan pendapatan/kesejahteraan masyarakat pesisir, member-dayakan masyarakat pesisir, dan memperkaya dan meningkatkan mutu sumberdaya alam.

Konsep pembangunan berkelanjutan adalah upaya yang bertujuan untuk mensinkronkan, mengintegrasikan, dan memberi bobot yang sama pada aspek utama pembangunan, yang meliputi tidak hanya aspek ekonomi, tetapi termasuk aspek yang melingkupinya, yaitu termasuk aspek sosial budaya dan aspek lingkungan hidup. Aspekaspek utama tersebut harus dipandang sebagai terkait erat satu sama lain, sehingga unsur-unsur dari kesatuan yang saling terkait ini tidak boleh dipisahkan atau dipertentangkan satu dengan lainnya.

Kondisi geografis dan demografis Indonesia membawa konsekuensi munculnya berbagai tantangan nyata bagi Indonesia yang harus dikelola secara komprehensif, yaitu; Membangun infrastruktur maritim seperti pelabuhan-pelabuhan; Pengembangan wilayah dan peningkatan aktivitas ekonomi; Sumber daya alam hayati di laut Indonesia seperti perikanan perlu dijaga dengan baik dari praktik-praktik perikanan yang tidak lestari; Pemanfaatan minyak, gas, mineral, arus, dan ombak untuk keperluan energi dan mineral masa depan.

Hasil tambang energi dan mineral dasar laut, memiliki nilai ekonomi yang sangat tinggi bagi kemajuan dan kesejahteraan Indonesia. Indonesia juga menghadapi tantangan untuk menambah luas yurisdiksi landas kontinen di luar 200 mil laut dan mampu melakukan eksplorasi di wilayah "The Area" Pengembangan jasa logistik pelabuhan, galangan kapal, dan wisata bahari. Kegiatan jasa kemaritiman dan eksploitasi sumber daya alam hayati dan nonhayati secara langsung dalam jangka pendek dan jangka panjang serta penghitungan ekonomi maritim pada tingkat nasional diperlukan untuk menilai secara objektif. Gerakan desentralisasi kelautan berawal dari era reformasi, perkembangan lingkungan strategis Indonesia mengalami perubahan pesat yang tidak pernah terbayangkan satu dekade lalu. Kemampuan nasional dalam pendidikan maritim, serta penguasaan dan pemanfaatan ilmu pengetahuan dan teknologi kelautan.

\section{DAFTAR PUSTAKA}

Afrizal, Metode Penelitian Kualitatif: Sebuah Upaya Mendukung Penggunaan Penelitian Kualitatif dalam Berbagai Ilmu. Jakarta: RajaGrafindo, 2014 
Kebijakan: Jurnal Ilmu Administrasi

Volume 12, Nomor 2, Juni 2021

E-ISSN: 2656-2820

P-ISSN 1829-5762

Asmara, A. Y. (2012). Penguatan Zona Ekonomi Ekslusif Dalam Pengelolaan Sumber Daya Maritim Indonesia Di Wilayah Perbatasan (Pembelajaran darim Kebijakan Pemerintah Norwegia Perihal Regulasi, Pemanfaatan Iptek, Manajemen Kelembagaan dan Kerjasama Internasional). J. Kebijakan Sosial Ekonomi Kelautan dan Perikanan, 2(2), 131-144.

Bungin, Burhan. Penelitian Kualitataif: Komunikasi, Kebijakan Publik dan Ilmu Sosial Lainnya. Jakarta: Kencana, 2017

FAO, 1995, Code of Conduct for Responsible Fisheries, Rome: Food and Agriculture Organization of The United Nations.

Josef Thessing dan Wilhelm Hofmeister (ed.), 1996, Environment and Development Protection as An Element of Order Policy, Rathausallee: KonradAdenauer Stiftung, hlm. 64, dalam A. Sonny Keraf, Ibid, hlm. 192.

Peraturan Presiden Republik Indonesia Nomor 16 Tahun 2017 Tentang Kebijakan Kelautan Indonesia.

Puspitarini, R. C., \& Yunus, M. (2019). Implementasi Tujuan Pembangunan Berkelanjutan Dalam Kebijakan Pengelolaan Maritim Berkelanjutan Melalui Larangan Penggunaan Cantrang. Jurnal Ilmiah Politik, Kebijakan, \&Sosial (Publicio), 1(2), 15-26.

Sutardjo, S. C. (2014). Kebijakan Pembangunan Kelautan dan Perikanan ke Depan Developmen Policy of Marine And Fisheries. Jurnal Kebijakan Perikanan Indonesia, 6(1), 37. https://doi.org/10.15578/jkpi.6.1.2014.37-42 